\title{
The Paradox Of German Power
}

\author{
Hans KUNDNANI, C. Hurst \&Co., London, 2016, 155 pages. ISBN: 978-1-84904-719-7
}

Adem AKKAYA $A^{1}$

Tarih tekerrür mü ediyor? İngiliz yazar Hans Kundnani, Londra merkezli bir düşünce kuruluşu olan Avrupa Dış İlişkiler Konseyi’ndeki çalışması sırasında kaleme aldığı ve hatırı sayılır oranda ses getiren Alman Gücünün Paradoksu (The Paradox of German Power) başlıklı çalışmasında bu sorunun cevabını aramıştır. Yazarın cevabını aradığı sorunun kökeni, esasında başlangıcı 1871 yılına dayanan ve hala üzerinde kafa yorulan "Alman Sorunu"ndan (German Question) başka bir şey değildir. Kundnani, bu çalışmasında 1945 sonrası büyük ölçüde çözüldügüne inanılan "Alman Sorunu"nun başka bir formda tekrar ortaya çıktığını ve özellikle Avrupa (Birliği) içerinde çeşitli sorunlara yol açtı̆̆ını dile getirmektedir.

Alman prensliklerinin 1871 yılında birleşmesiyle Avrupa'nın merkezinde ortaya çıan Almanya, Avrupa güçler dengesinin (balance of power) bozulmasına sebep olduğu gibi askeri, coğrafi ve teknolojik imkânlarıyla Avrupa'nın en güçlü devletlerinden biri halini almıştır. Almanya'nın kuruluşundan itibaren izlediği güç politikası ve buna paralel olarak Bismarck'ın izlediği reel politik diplomasi (Bismarckian diplomacy) dönemin uluslararası yapısı, güç ilişkileri, ittifak sistemleri üzerinde değişiklikleri zaruri hale getirmiş̧ir. Alman imparatoru II. Wilhelm ile beraber sömürgecilik alanında girişilen mücadele ve askeri enstrümanlarla uygulanmak istenen dünya politikası (Weltpolitik) “Alman Sorunu”nun iyice büyümesine sebep olmuştur. 1871 yılında başlayan bu "sorun" iki dünya savaşının da müsebbibi sayılmış, çözüm olarak ise; içselleştirilmiş liberal demokratik değerler ve güçlü bir Avrupa entegrasyonu fikri benimsenmiştir. Konrad Adenauer önderliğinde hayata geçirilen Westbindung ${ }^{2}$ tam da bu amaçlarla uyumlu bir şekilde, Almanya için Avrupa'yla kalıcı bir entegrasyonu ve kurumsallaşmayı, batılı müttefikleriyle çok taraflı işbirliğini (multilateralism) ve güvenlik bağlamında NATO'yla sık ilişkileri ifade etmekteydi. Dolayısıyla, yazarın 1871-1945 yılları arasında "jeopolitik yarı hegemon" olarak tanımladığı Almanya ve onun ortaya çıkardığı Alman Sorunu bu şekliyle çözüme ulaşmış kabul edilmiştir.

Kundnani'nin, tarih tekerrür mü ediyor sorusuyla başlattığı çalışmasında irdelediği ve analizini sonuca ulaştırmaya çalışırken devamlı bir şekilde ele aldığ 1 konu ise, Almanya'nın güç potansiyeli ve bunun yansımasıdır. Soğuk Savaş'ın bitimiyle Avrupa'nın dönüşüme uğradığını, Almanya'nın coğrafi konumu itibariyle eski avantajlarını kazandığını (Mittelage) ve Avrupa'nın merkezinde önemli bir güç olarak tekrar yükseldiğini ileri süren yazar, bununla birlikte önceki dönemden farklı olarak Almanya'nın etrafının düşmanlarla çevrili olmadığını, tam aksine Avrupa Birliği ve NATO üyesi müttefikleriyle bir arada konumlandığını söylemektedir. Dolayısıyla, 18711945 arası dönemde yazar tarafından jeopolitik bir hegemon olarak tanımlanan Almanya'nın aksine, günümüz Almanya'sı söz konusu dönemle benzer bir üstünlüğe askeri güçten farklı bir araçla sahiptir. Bu bağlamda, Kundnani'nin çalışması boyunca temel tezi olan ve tüm argümanlarını bu doğrultuda açıklayan görüşü ise Almanya'nın artık ekonomik bir güç olduğu ve jeopolitik yarı hegemonyadan jeo-ekonomik yarı hegemonyaya (geo-economic semi-hegemony) doğru evirildiğidir. Yazar, çalışmasında bu fikrini, Yunanistan'ın, borç krizi esnasında Avrupa Birliği ortak para birimi

\footnotetext{
${ }^{1}$ Arş. Gör., Niğgde Ömer Halisdemir Üniversitesi, İ̈BF, aakkaya@ohu.edu.tr

${ }^{2}$ Westbindung; 1949 yılında Şansölye Adenauer ile birlikte politik, ekonomik ve askeri bakımlardan Batıyla entegre olma ve dış politikasını bu minvalde uygulama anlamında kullanılan Almanca kavramdır.
} 
Euro'dan ve hatta Avrupa Birliği’nden (Greexit) çıkma ihtimaline karşın Almanya'nın yürüttüğü diplomasi üzerinden kanıtlamaya çalışmıştır.

Kundnani, kitabında ekonomi-politiği merkeze alan bir kavramsal çerçeveyle Alman milliyetçiliği ve Alman dış politikasının değişimi üzerine de çeşitli varsayımlarda bulunmuştur. $\mathrm{Bu}$ bağlamda, yazar Alman milliyetçiliğinin barış ve ihracat üzerine kurulu hale geldiğini (Kundnani, 2016: 113), dış politikanın ise idealizmden realizme doğru dönüştüğünü iddia etmektedir (Kundnani:2016: 23-38). Alman diplomasisinin kendi tercihlerini diğer ülkelere dayatmada çok daha istekli olduğunu belirten yazar, Avrupa içerisindeki diğer ülkelerin ekonomilerinin Almanya'yla rekabet edebilecek düzeyde olmadığını belirtmektedir. Buradan hareketle, Euro Krizi esnasında Almanya'nın ortaya koyduğu liderliğin hegemonya tartışmalarını tekrar başlattığı düşüncesi hâkimdir.

Hans Kundnani, kitabın birinci bölümünde tarihi arka planıyla birlikte ele aldığ 1 Alman Sorununun, Almanya'nın mevcut ekonomik durumunu göz önünde bulundurarak tekrar ortaya çıktığını iddia etmektedir. Bahsi geçtiği üzere diğer üye ülkelerle kıyaslanamayacak olduğu düşünülen Alman ekonomisi, bu haliyle Avrupa içerisinde bir istikrarsızlığa (instability) sebep olabilme potansiyeli olarak görülmüsstür (Kundnani, 2016: 110). Euro Krizi esnasında, Yunanistan ile yürütülen müzakerelerde ortaya konan taviz vermez Alman tavrı, hegemonya tartışmalarının yanı sıra eski korkuların tekrar su yüzüne çıkmasına da sebebiyet vermiştir. Kundnani, müzakereler esnasında basın yayın organlarınca ve gösterilerde Almanya'ya karşı oluşan durumu ve MerkelHitler mukayeselerini bu minvalde örnek vakalar olarak göstermektedir. (Kundnani, 2016: 3,90).

Çalışmanın başlığı ve konusu olan Alman gücünün paradoksu nedir? Bu sorunun iki cevabı bulunmaktadır. $\mathrm{Bu}$ cevaplardan sadece bir tanesi, çalışma içerisinde açıça belirtilip detaylandırılmaktadır. Kundnani, Alman gücünün paradoksunu istekli/iddialı ekonomi politikalarına karşın askeri manada isteksizliği olarak tanımlamaktadır (Kundnani, 2016: 103). Aslında bu, Alman dış politikası için yeni bir durum değildir. Klasik Alman dış politikasının güç kullanımına (use of power) ve liderlik etmeye ilişkin kendine biçtiği kısıtlanma kültürü (culture of restrain) bu durumla alakalıdır. Buna karşılık, Kundnani yükselen Alman gücüne ve Alman dış politikasının değişimine karşın Avrupa'nın tarihsel belleğinde derin izleri olan Alman geçmişine çok değinmemiştir. Alman gücünün diğer bir çıkmazı da Avrupalıların belleğinde yer etmiş olan, unutulamayan Almanya'nın geçmiş uygulamalarıdır. Dolayısıyla, hegemonya tartışmalarına Gramsci'nin materyal gücün yanında "rızaya/kabule" dayanan hegemonya yaklaşımıyla bakıldığında Almanya'nın liderlik etmede kabul alması oldukça zor görünmektedir. Çalışmanın eleştirilebilir taraflarından birisi de bu konudaki detaylandırmanın yüzeysel kalmasıdır.

The Paradox of German Power, özü itibariyle ekonomik bir perspektiften yapılan ve sonuca ulaşılan Alman dış politika çalışmasıdır. Ekonomi- politik bir bakışla, Avrupa'nın ortasında tarihsel Alman Sorununun tekrar ortaya çıktığını ve istikrarsızlığa yol açtığını söylemesi çalışmayı dikkate değer kılmaktadır. İddialı olmasının yanında, Almanya'nın mevcut gücünün ve liderliğinin Fransa'nın görece zayıf durumundan kaynaklandığını söyleyecek geniş bir bakış açısına ve objektifliğe de sahiptir. Yine, tamamen ihracata, dolayısıyla ekonomiye bağlı bir değerlendirmeyle, BRIC $^{3}$ ülkeleriyle birlikte Mart 2011 tarihinde Birleşmiş Milletler Güvenlik Konseyi'nde NATO'nun Libya'ya müdahalesiyle ilgili oylamada çekimser kalan Almanya'nın, sermayenin doğuya kaymasına paralel olarak dış politika kararlarını değiştirdiğine değinilmiştir (Kundnani, 2016: 4). Bu da Alman dış politikasına dair güncel tartışmaların önemli bir tarafına çalışmada değinilmesi açısından oldukça önemlidir. Yalın bir ekonomik realizm olarak adlandırılabilecek bir yaklaşımla Alman dış politikasının açıklanmaya çalışılması indirgemeci haliyle tartışmaya açıktır. Alman dış politikası analizinde ekonomik boyut çok önemli bir yer tutmakla birlikte, ekonomi her şey değildir. Bununla birlikte, Alman diş politikasını ekonomik boyuttan okumak anlamak ve sonuçlandırmak isteyenler içinse yol gösterici ve ufuk açıcı nitelikte bir eser olarak görülmektedir.

Çalışmanın kurgusu varılmak istenen sonuçla birlikte düşünüldüğünde okuyucular için doğrusal bir yol izlemektedir. Yazar, giriş kısmında ortaya attığı soruyla varmak istediği sonucu

\footnotetext{
${ }^{3}$ BRIC; Brezilya, Rusya, Hindistan ve Çin Halk Cumhuriyeti ülkelerinin oluşturduğu gruba verilen bir kısaltmadır.
} 
ortaya koymaktadır. Tarih tekerrür mü ediyor sorusuyla çalışmasına başlayan Kundnani, Alman dış politikasına dair güncel tartışmaları ve soruları bu bölümde ortaya koymakta, çalışmasının temel yapısını açıklamaktadır. Avrupalılaşan bir Almanya mı yoksa Almanyalılaşan bir Avrupa mı? Alman dış politikasına dair uzun yıllar önce sorulan bu klasik soruyu yazar, mevcut şartlar ve gelişmeler ışı̆̆ında analiz edeceğini giriş kısmında belirtmektedir.

Altı bölümden oluşan kitabın ilk bölümünde yazar, öze dayalı ve oldukça besleyici bir biçimde, 1871'de Almanya'nın birleşmesiyle başlayan ve II. Dünya Savaşı'nın sonuna kadar çözümü bulunamayan "Alman Sorunu”nu açılamaktadır. Bu bölümde, Bismarck önderliğinde Almanya’nın birleşmesine giden yol hakkında kısa bilgiler verilip, tarihsel ve sosyolojik bir inceleme yapılmıştır. Ayrıca, birleşen Almanya'nın coğrafi, askeri ve teknolojik olarak önemli bir güç oluşturduğu, bu olanakları demografik büyüklüğüyle de birleştirdiğini, bunların ise Avrupa güçler dengesini bozduğu yine bu kısımda anlatılmaktadır. Yazar bu bölümde, Almanya'nın birleşmesiyle başlayan ve Bismarck'ın ihtiyatlı politikalarına rağmen Weltpolitik ile birleşen "Alman Sorunu”nun, 1945 "e kadar olan tarihsel akışını inceleyerek, ileriki bölümlerde irdeleyeceği Avrupa'daki Alman hegemonyası, yeni Alman sorunu gibi konuların anlaşılmasına ve mukayese edilebilmesine zemin hazırlamıştır.

İkinci bölümden başlayarak yazar, Alman dış politikasına dair tartışmaların içine girmiştir. İdealizm ve Realizm başlıklı üçüncü bölümde Kundnani, 1945-1990 arası Alman dış politikasının genel bir analizini yapmıştır. Nazi geçmişinin Alman dış politikasındaki etkileri, sivil güç (civilian power), ticaret devleti (trade state), kurumsallaşmacı dış politika yapısı, Avrupa entegrasyonu gibi Alman dış politikasını açıklayan temel kavram ve olaylar yetkin isimlere gösterilen referanslarla açıklanmıştır. Bu dönem, Alman dış politikasında idealizm olarak gösterilmiştir.

Değişim ve devamlılık tartışmalarının tartışıldığı üçüncü bölüm, günümüz Alman dış politikasının da en çok tartışıldığı alandır. Bu tartışmanın ortaya çıkmasına iki olay zemin hazırlamıştır: İki Almanya'nın tekrar birleşmesi ve Soğuk Savaşın bitmesi. Soğuk Savaşın bitmesi ve iki Almanya'nın yeniden birleşmesi birbirine paralel iki olaydır. Buradaki soru ise; yeniden birleşen Almanya'nın yeniden şekillenen uluslararası yapı içerisinde kendi dış politikasını nasıl yöneteceği ile alakalıdır. Almanya, savaş sonrası dönemde olduğu gibi Westbindung'a sadık kalarak kısıtlanma kültürü içerisinde devam mı edecekti yoksa tek taraflılık (uniliteralism) ve güç politikası üzerine kurulu yeni bir yola mı girecekti? Yazar bu bölümde, 1990 sonrası Alman dış politikasının bazı örnekleriyle bu durumu ortaya koymaya çalışmıştır.

Dördüncü bölüm, özellikle 2000 sonrası Alman dış politikasının incelendiği bölümdür. $\mathrm{Bu}$ bölümde, 11 Eylül Olayı ve 2003 Irak işgali sonrası Almanya- ABD ilişkileri ele alınmıştır. Özellikle, 1998 yılında Almanya'da iktidar olan Schröder'in ABD ile ilişkileri ve Irak Savaşı'na karşı geliş okuyucuyu bilgilendirici düzeydedir.

Beşinci bölümde yazar, Almanya'nın ekonomi politikalarına ve uluslararası ekonomik durumu açıklamaya çalışmıştır. Bu bölümde, Almanya'nın ekonomik iyileşmesini ve reformlarını açıklayıcı bir üslupla okuyucuya aktaran Kundnani, Almanya'nın dış yardımlarından ve doğrudan yatırımlarından da bahsetmektedir. Ayrıca, Yunanistan'ın yaşadığı borç krizine ve buna yönelik Alman tepkisi de bu bölümde irdelenmiştir. Son olarak, uluslararası ekonominin yeni merkezlerine atıflar yapılmış, Çin bu bağlamda ön plana çıkarılmıştır.

Avrupa ve Dünya başl1klı son bölümde ise yazar, artık kurgusuna sonuca oluşturacak temel argümanları derinlemesine incelemeye başlamıştır. Kundnani, Alman dış politika algısının değişimine, Yunanistan'ın borç krizindeki liderliğine ve dominant ekonomik hedeflerin Almanya'nın Avrupa ötesi dünyayla kurduğu ilişkilerdeki belirleyici tarafını bu bölümde aktarmaktadır.

Sonuç bölümünde ise yazar, Almanya'nın ekonomik bir yarı hegemonya oluşturduğu kanısına vardığını gerekçelendirmeleriyle birlikte okuyuculara aktarmaktadır. Almanya'nın sahip olduğu ekonomik büyüklüğüne rağmen güç kullanma ve liderlik etme noktalarındaki isteksizliğini Alman gücünün paradoksu olarak gören yazar, Alman sorununu ise, Almanya'nın ekonomik kapasitesine cevap verebilecek ve bu noktada onunla rekabet edebilecek herhangi bir Avrupa ülkesinin olmamasının yaratacağı istikrarsızlık olarak görmektedir. 